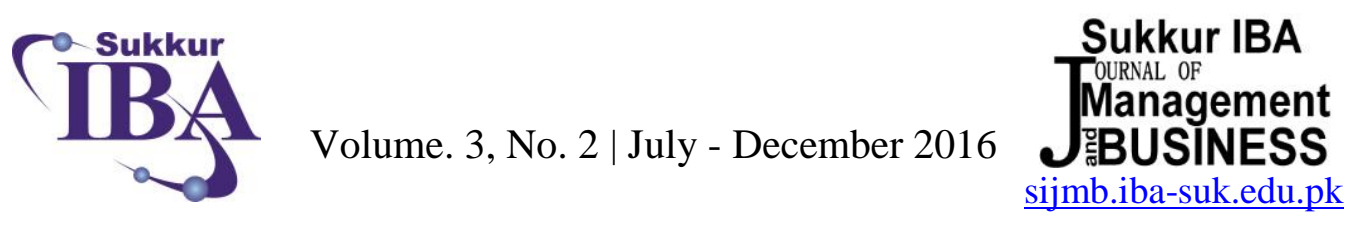

\title{
The Relationship between Transformational Leadership and Job Performance: An Empirical Investigation
}

\author{
Syed Mir Muhammad Shah*1 \\ Sukkur Institute of Business Administration, Pakistan \\ Abdul Halim bin Abdul Majid ${ }^{2}$ \\ School of Business Management, Universiti Utara Malaysia \\ Altaf Hussain Samo ${ }^{3}$ \\ Sukkur Institute of Business Administration, Pakistan \\ Pervaiz Ahmed Memon ${ }^{4}$ \\ Sukkur Institute of Business Administration, Pakistan
}

\begin{abstract}
:
The main objective of the present paper is to assess the relationship between transformational leadership and job performance empirically. The study was conducted in the banking sector of Pakistan focusing on six large banks. A total number of 308 responses were collected through survey questionnaire from the bank managers. The data was then coded into SPSS for early stage analysis such as data screening. This was followed through applying SmartPLS to analyze the data and the results have been presented in its standard reporting style. The findings revealed a positive relationship between transformational leadership and job performance in banking sector of Pakistan supporting the hypothesized relationship. Finally, the paper has presented a way forward for future research.
\end{abstract}

Keywords: Transformational Leadership, Job Performance, Banks, Pakistan, SmartPLS

https://doi.org/10.30537/sijmb.v3i2.96

${ }^{*}$ Corresponding Author

${ }^{1}$ syedmir@iba-suk.edu.pk

2 ahalim@uum.edu.my

3 altaf@iba-suk.edu.pk

4 pervaiz@iba-suk.edu.pk

SIJMB | E-ISSN: 2410-1885; P-ISSN: 2313-1217 @ 2016 Sukkur Institute of Business Administration - All rights reserved 


\section{Introduction}

Leadership is considered very crucial for accelerating the improvements in the corporate settings. It also potentially influences job performance of individual employees. This is true due to the fact that leadership possesses the ability to motivate, guide followers to realize mission, vision and objectives of the organization. It also helps employees in order to be innovative and creative for the promotion of new ideas. Similarly, leadership is well recognized due to the fact that it helps employees and organizations in adapting emerging changes, building teamwork and improving their overall capabilities. Therefore, it becomes necessary to evaluate the influence of leadership over individuals as well as organizational performances.

In this vein, academic scholars have mutually agreed that the ultimate success of the business organizations depends on the connections between the leader and their followers (Chu, Yang, and Chen (2011); Lau and Tong (2008); Wang, Oh, Courtright, and Colbert (2011)).This relationship based alignment becomes critical as the leaders need to prepare their followers for adapting to the continuous change processes, face turbulent technologies, cultural changes and more importantly the ever-changing environmental challenges (Chu et al. (2011); Wang et al. (2011)). Although there is a huge stream of literature on leadership that speaks about several leadership styles, the prominent amongst them have been transformational, transactional, and laissez-faire Bass (1985). However, the recent research has revealed that transformational leadership stands more effective in influencing employee performance and has been called as a most significant benchmark in the business organizations (Levy, Cober, and Miller (2002); Sarros and Santora (2001)).

Therefore, the main objective of the present study was to replicate the influence of transformational leadership over job performance in the six large banks of Pakistan. This investigation holds importance due to several reasons. First, such an investigation has not been made in the six large banking sector context of Pakistan. As a result, there has been lack of clarity in terms of how well transformational leadership could influence the individual job performance. Second, the present study has conceptualized job performance on the basis of two important elements, namely, task performance and organizational citizenship behavior, as such as investigation has not been made earlier in the Pakistani context. Third, the findings of the present study have presented insights that have been in line with the studies that have specifically been conducted in the developed context, such results have enriched the prevailing literature on transformational leadership by providing empirical evidence on its effectiveness in the banking sector in Pakistan. Last, the literature on the proposed relationship and job performance has been reported inconsistent (Dolatabadi and Safa (2010); Mohammad Mosadegh Rad and Hossein Yarmohammadian (2006); Shah, Hamid, and Bin (2015); Voon, Lo, Ngui, and Ayob (2011)). Therefore, this has encouraged the present study to further investigate the proposed relationship under LMX theory Graen (1976).

Sukkur IBA Journal of Management and Business | Volume 3 No. 2 July - December 2016 @ Sukkur Institute of Business Administration 


\section{Review of the Literature}

The effectiveness employee's behaviors for meeting job related objectives have been denoted as job performance McCloy, Campbell, and Cudeck (1994). However, researchers have differently conceptualized the notion of job performance. However, this addressed notion has remained centrally important because it critically contributes to the overall organizational performance Organ (1977).

According to Campbell (1990) job performance is an important construct in organizational psychology as well as in human resource management. Whereas Jamal (2007) determined job performance as an individual's function carrying out efficiently within the prevailing constraints and the resources available. The meaning of Job performance varies depending upon job to job. Some researchers including Campbell (1990) have developed broader scope of performance which can be generalized for various jobs. Campbell introduced eight factors related to job performance a) job specific proficiency, b) non-job specific task proficiency, c) Effort to Demonstrate, d) written and oral communication, e) to maintain personal discipline, f) marinating team and peer performance, g) supervision and leadership, h) administration and management. He further was of the opinion that all factors are not relevant towards all jobs and all of these factors can be used to portray job performance for any possible occupation. Moreover, all factors and content of factors varies from job to job, primarily each factor is one of motivational element. The study conducted by Hochwarter, Kiewitz, Gundlach, and Stoner (2004) has further added social worth towards all these factors. The scholars have pointed out that job performance is a multidimensional concept which consists of task related performance and contextual elements highlighting the social skills predicting as job performance. A huge amount of research has been conducted in order to understand the main variations among employees and their job performance. The studies conducted by Beck, Behr and Beck, Behr, and Guettler (2012) on gender, Ittner, Larcker, and Pizzini (2007) on salary, Ng and Feldman (2008) age, Hourani, Williams, and Kress (2006) on stress, have determined that all these variables have relationship with job performance.

More importantly, the mature literature on job performance has highlighted two core components namely, task performance and OCB (Borman and Motowidlo (2014); Motowildo, Borman, and Schmit (1997); Organ (1988)). According to Lee, Tan, and Javalgi (2010) task performance or in role performance are those behaviors which are directly related to the responsibilities, duties and tasks which are prescribed and are documented in job description. Kanter (1988) has conceptualized task performance as innovative performance, which refers the qualities of the employees' skills like creativity and problem solving techniques at workplace. Likewise OCB or extra role behavior is important at work place to be innovative to generate, promote and to realize creative ideas to bring organizational successes (Janssen and Van Yperen (2004); Lee et al. (2010)). According to (Austin and Villanova (1992)), every individual is different in several ways in relation to job role behaviors where measures are criteria to identify

Sukkur IBA Journal of Management and Business | Volume 3 No. 2 July - December 2016 ○ Sukkur Institute of Business Administration 
such differences. A large number of constituencies have used such criteria for measures used in applied psychology. Some of them used evaluation criteria as work behavior theories some used effective human resources administration and some used provision for feedback to the individuals. As a result, however, an index that measures the significance of the observation that most, if not all, of the pioneers of industrialorganizational psychology has addressed this issue during his career. The paper reviews the development of conceptual and methodological problems related to the standard of 1917, as the size of the organization, methods of measurement, analysis, and use the classification framework competing values from which to view performance metrics.

Regardless of an extensive history of apprehension on issues of condition, the construct of the employee performance has not yet been mapped completely. Campbell (1990), Motowidlo and Van Scotter (1994) argued that the investigation of employment complicated techniques is accessible to recognize the tasks and significant behaviors, but their focal point is mainly experimental and normally precise jobs or job families. Therefore, they have not formed reasonable hypothetically fundamental underlying dimensions which can be used to portray the performance necessities of jobs in allpurpose. More theoretical attempts to divide the area of performance are opening to confirm hopeful symbols. They adopt extremely unusual conceptual orientations, dissimilar investigative approaches to conventional employment and the other, but they unite on the difference between task performance and contextual performance (Borman and Motowidlo (1993); Borman and Motowidlo (2014); Motowidlo and Van Scotter (1994); Shah et al. (2015)). As reported in Motowidlo and Van Scotter (1994), Katz and Kahn (1978) state that theoretical scheme is more fundamental for the job performance and partitioning is tripartite splitting up between i) to join the organization and remain in, ii) to meet the expected standards or even exceeding standards as framed by organization, and iii) be innovative, and spontaneous to go ahead of the roles and actions in terms of cooperation with all members, giving suggestions to bring improvements, protection against harm, carry out personal development and building the image of organization. Further, Orr, Sackett, and Mercer (1989) have confirmed about the importance of two actions by providing empirical support on it. Their study showed that at least few supervisors are inclined to prescribed and flexible behaviors in consideration in measuring dollar value on job performance for hypothetical analyst for the programmers.

The transformational leadership style is the one that seeks to uplift the wishes of the individual followers for their desired achievements and also for self-development. On the other hand, it promotes development for the group as well as the organization Bass and Avolio (1990) and motivating the followers to produce the output more than it is desired originally expected Bass (1985). More specifically, transformational leaders influence their followers, and they operate as a role model for succeeding leaders. They provide encouragement and inspirational motivation to the subordinates. They also exhibit individualized consideration, acting as coaches and mentors, contribute to the

Sukkur IBA Journal of Management and Business | Volume 3 No. 2 July - December 2016 @ Sukkur Institute of Business Administration 
development of their subordinates to reach high skills and goals, and make struggle to meet up their subordinates' requirements for development and success. Finally, transformational leaders present intellectual stimulation by cheering and inspiring to become innovative and creative to see their issues from different angles, and to form diverse ways for resolving those issues. They give confidence to their subordinates to face challenges and try different approaches to achieve success Bass and Riggio (2006). Therefore, the transformational leaders build up a strong stand to transport a transformational change in organization. The study conducted by Alimo-Metcalfe and Alban-Metcalfe (2005) considered as an extensive study which is based on more than 3,500 respondents in United Kingdom by using 360 degree feedback method reinforced the argument that the ability of the leader, specifically transformational leader is crucial at all levels of organization and very critical to cope up changes for organizational development.

\subsection{Transformational Leadership and Job Performance}

Literature provides sufficient evidence that leadership positively influences organizational outcomes (Bass, Avolio, Jung, \& Berson, 2003; Luthans, Avey, Avolio, and Peterson (2010)). More specifically, scholars have empirically suggested that leadership styles influence job performance significantly Howell \& Avolio, (1993). Further to this notion, the past researchers have also been interested in investigating the individual influence of each of the leadership style over job performance. In doing so, the researchers have revealed that out of many varying leadership styles the most prominent variables have been transformational and transactional leadership styles (Avolio, Bass, and Zhu (2004); Ehrhart (2004); Whetstone (2002)). Further to these evidences from the literature, it has also been reported in the past studies that transformational leadership alone holds greater influence over job performance when compared to transactional leadership style Gardner and Stough (2002). The same assertion of the effectiveness of transformational leadership over transactional leadership has been conferred by several studies. Refer for example, (Bass et al. (2003); Dvir, Eden, Avolio, and Shamir (2002)). Similarly, while investigating transformational leadership along with organizational and individual job performance, studies have provided strong empirical evidence (Argyris and Schön (1996); Glynn (1996); Hurley and Hult (1998)). The transformational leadership has also been regarded as an important variable in the literature of leadership due to the fact that it drives the followers in setting and meeting their respective job related objectives Kelman (1958).

Apart from the above evidence on the influence of transformational leadership over job performance, the literature has also suggested findings that are inconsistent (Dolatabadi and Safa (2010); Mohammad Mosadegh Rad and Hossein Yarmohammadian (2006); Voon et al. (2011)). Therefore, the present study, in the light of leader member exchange (LMX) theory Graen (1976) aimed at investigating the postulated relationship between transformational leadership and job performance in the banking sector of Pakistan.

Sukkur IBA Journal of Management and Business | Volume 3 No. 2 July - December 2016 @ Sukkur Institute of Business Administration 


\section{Methodology}

\subsection{Sample and Population}

The data was collected from branch managers for reporting an appropriate description of the role of leadership over job performance. For this reason, 302 responses were collected from a total 1314 population of branch managers of six large banks of Pakistan. The sample for the population was drawn following Krejcie and Morgan (1970). Further, the present study used the proportionate random sampling technique, after initial screening 297 cases were used for the final analysis.

\subsection{Instrumentation}

The dependent variable job performance that consisted of task and OCB as a subcomponents, was measured using job performance scale developed by Williams and Anderson (1991) with 37 items and Transactional leadership was measured using Multifactor Leadership Questionnaire (MLQ) developed by Bass and Avolio (1995) with 12 items. The survey participants were asked to self-evaluate perceived job performance and transactional leadership style on a five point Likert scale with 1 indicating (strongly disagree) and 5 as (strongly agree) was employed.

\subsection{Demographics}

A larger proportion of the survey participants were male $(94.9 \%)$. However, the majority of respondents were in 31 to 40 years of age group with $39.1 \%$ and lowest percent falls in 51 or above age group that is with 8.1 percent. $84.2 \%$ managers were married and $15.8 \%$ are unmarried. A larger portion of managers comprised graduates with $91.2 \%$ whereas, undergraduate were $7.4 \%$. The major two groups of the managers have salaries PKR 40,000 or less with $21.5 \%$ and PKR 80,000 or above with $21.2 \%$. The detailed demographics of the respondents are given in Table 1.

Table 1: Demographic Profile of Respondents

\begin{tabular}{lll}
\hline Characteristics & Frequency & Percentage \\
\hline Gender & 282 & \\
Male & 14 & 94.9 \\
Female & & 4.7 \\
Age & 74 & \\
20-30 years & 116 & 24.9 \\
31-40 years & 82 & 39.1 \\
41-50 years & 24 & 27.6 \\
51 and above & & 8.1 \\
Position & 155 & 52.2 \\
Branch Manager & 141 & 47.5 \\
Operations Manager & & \\
Experience & 46 & 15.5 \\
Less than five years & 117 & 39.4 \\
5 to less than 10 years & & \\
\hline & $==============================================================================$ \\
\end{tabular}

Sukkur IBA Journal of Management and Business | Volume 3 No. 2 July - December 2016 @ Sukkur Institute of Business Administration 
M. Shah et al. / The Relationship between Transformational Leadership and Job Performance: An Empirical

\begin{tabular}{lll}
\hline 10 to Less than 15 & 49 & 16.5 \\
15 to less than 20 & 32 & 10.8 \\
20 to less than 25 & 17 & 5.7 \\
25 to less than 30 & 15 & 5.1 \\
30 and above & 21 & 7.1 \\
Qualification & & \\
Undergraduate & 22 & 7.4 \\
Graduate & 271 & 91.2 \\
Post Graduate & 4 & 1.3 \\
Monthly Income & & \\
$40 \mathrm{~K}$ or less & 64 & 21.5 \\
41 to 50 K & 56 & 18.9 \\
51 to 60K & 51 & 17.2 \\
61 to $70 \mathrm{~K}$ & 33 & 11.1 \\
71 to $80 \mathrm{~K}$ & 30 & 10.1 \\
81 to above & 63 & 21.2 \\
Marital Status & & \\
Married & 250 & 84.2 \\
Unmarried & 47 & 15.8 \\
\hline
\end{tabular}

\section{Analysis and Results}

The present study employed Partial Least Square (PLS) path modeling Wold, (1974) for the analysis of the study variables. In this connection specifically the study used (Smart PLS) Ringle, Wende, and Will (2005) due to its user friendly nature and robust results.

\subsection{Measurement Model Results}

The individual item reliability, internal consistency reliability and discriminant validity were ensured for reporting reliability and validity of the study. First, for assessing individual item reliability the outer loadings were used Hair, Sarstedt, Ringle, and Mena (2012).

Table 1: Measurement Model Results

\begin{tabular}{cllll}
\hline Latent Variables & $\underline{\text { Items }}$ & $\underline{\text { Loadings }}$ & $\underline{\mathbf{A V E}}$ & $\underline{\mathbf{C R}}$ \\
\hline OCB & JPOCB28 & 0.635 & 0.507887 & 0.877521 \\
& JPOCB32 & 0.6434 & & \\
JPOCB33 & 0.7902 & & \\
JPOCB34 & 0.759 & & \\
& JPOCB35 & 0.7744 & & \\
& JPOCB36 & 0.6335 & & \\
\hline
\end{tabular}

Sukkur IBA Journal of Management and Business | Volume 3 No. 2 July - December 2016 @ Sukkur Institute of Business Administration 
M. Shah et al. / The Relationship between Transformational Leadership and Job Performance: An Empirical

\begin{tabular}{lclll}
\hline & & & & \\
\hline \multirow{2}{*}{ Task } & JPOCB37 & 0.7325 & & \\
& JPTSK1 & 0.8404 & 0.568272 & 0.793599 \\
TRFIC & JPTSK2 & 0.8201 & & \\
& JPTSK3 & 0.571 & & \\
TRFIIA & LS26 & 0.6936 & 0.542949 & 0.702952 \\
& LS28 & 0.7778 & & \\
TRFIIB & LS16 & 0.7393 & 0.589992 & 0.741363 \\
& LS23 & 0.7968 & & \\
TRFIM & LS12 & 0.784 & 0.650021 & 0.787785 \\
& LS30 & 0.8278 & & \\
TRFIS & LS24 & 0.8256 & 0.629303 & 0.772284 \\
& LS7 & 0.7592 & & \\
& LS27 & 0.7374 & 0.632447 & 0.774052 \\
\hline
\end{tabular}

Table 2: Discriminant Validity

\begin{tabular}{llllllll}
\hline & $\underline{1}$ & $\underline{2}$ & $\underline{3}$ & $\underline{4}$ & $\underline{\mathbf{5}}$ & $\underline{6}$ & $\underline{7}$ \\
\hline OCB & $\mathbf{0 . 7 1 2}$ & & & & & & \\
TRFIC & 0.347 & $\mathbf{0 . 7 3 6}$ & & & & & \\
TRFIIA & 0.299 & 0.332 & $\mathbf{0 . 7 6 8}$ & & & & \\
TRFIIB & 0.356 & 0.414 & 0.327 & $\mathbf{0 . 8 0 6}$ & & & \\
TRFIM & 0.309 & 0.408 & 0.453 & 0.383 & $\mathbf{0 . 7 9 3}$ & & \\
TRFIS & 0.328 & 0.501 & 0.356 & 0.445 & 0.326 & $\mathbf{0 . 7 9 5}$ & \\
Task & 0.298 & 0.362 & 0.376 & 0.431 & 0.368 & 0.404 & $\mathbf{0 . 7 5 3}$ \\
\hline
\end{tabular}

Note: Bold diagonal figures are the square root of AVE while others represent correlations.

The present study retained 0.5 and above loadings (Barclay, Higgins, and Thompson (1995); Chin (1998)) refers Table 1.Moreover, for determining the internal consistency reliability the composite reliability coefficients were used (Bagozzi and Yi (1988); Hair, Ringle, and Sarstedt (2011)). Accordingly, the composite reliability should be at least 0.7 or above (Table 1). Hence, the present study successfully met the internal consistency reliability.

Next, the discriminant validity was ascertained using AVE following Fornell and Larcker (1981). According to whom, the square root of AVE should be greater than the correlations among latent variables.

Sukkur IBA Journal of Management and Business | Volume 3 No. 2 July - December 2016 ○ Sukkur Institute of Business Administration 
M. Shah et al. / The Relationship between Transformational Leadership and Job Performance: An Empirical

\subsection{Structural Model Results}

The bootstrapping approach was used for assessing path coefficients with 5000 bootstraps and 297 cases Hair et al. (2012). The results of the bootstraps are provided in Table 3 and Figure 1.

Table 3: Path Coefficients and Hypothesis testing

\begin{tabular}{llllll}
\hline Relationship & Beta & SE & t-statistics & Decision \\
\hline $\begin{array}{l}\text { Transformational Leadership } \\
\text { Job-Performance }\end{array}$ & 0.11111 & 0.033051 & 3.361784 & Supported \\
\hline
\end{tabular}

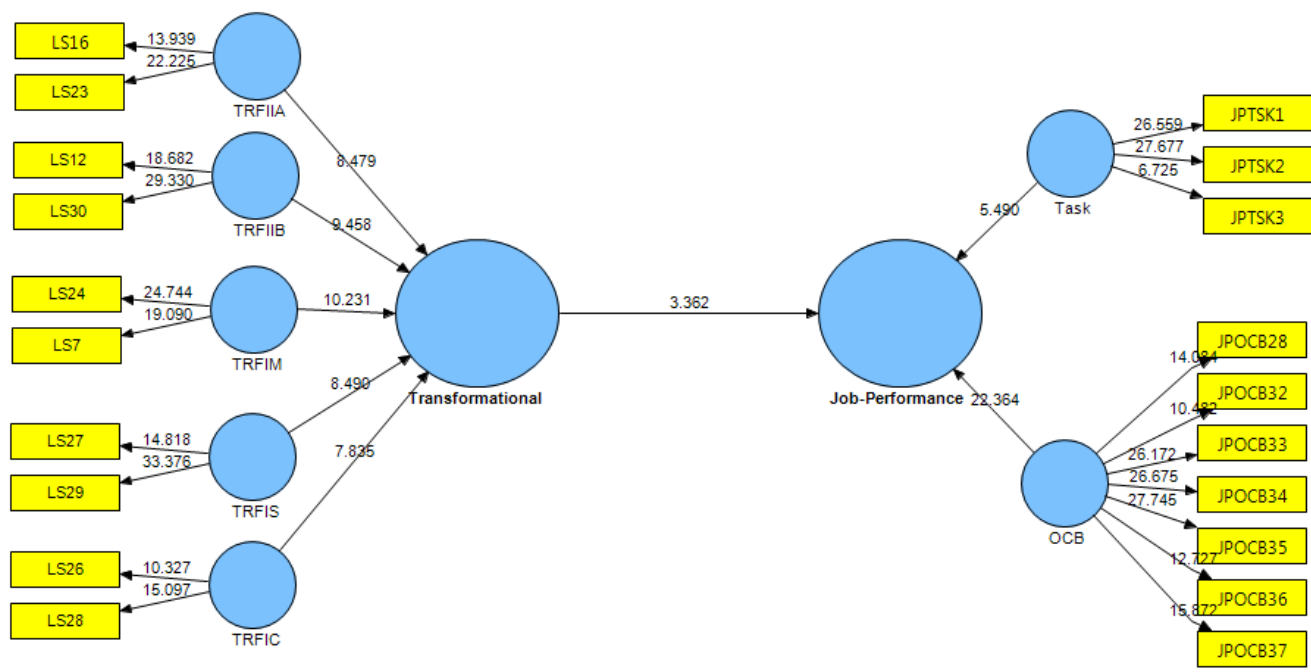

Figure 1: structure model assessment

The results of the bootstraps have revealed a significant relationship between transformational leadership and job performance (beta $=0.11, \mathrm{t}=3.36$ ), thus, supporting the proposed hypothesis. Next, the present study provides the r-square assessment. According to the results provided in Table 4, it is suggested that the transformational leadership has explained a variance of 8.7 percent.

Table 4: Variance Explained in the Endogenous Variable

\begin{tabular}{ll}
\hline Latent Variable & Variance Explained \\
\hline Job performance & $8.7 \%$ \\
\hline
\end{tabular}

Sukkur IBA Journal of Management and Business | Volume 3 No. 2 July - December 2016 @ Sukkur Institute of Business Administration 


\section{Discussion}

The main objective of the study was assessing the transformational leadership and job performance relationship in the six large banks of Pakistan. The result of the study has revealed that transformational leadership is positively associated with job performance. This assertion informs that the branch managers in the six large banks of Pakistan perceive that their leadership uplifts their desires and wishes for overall accomplishments and the self-development of individuals Bass and Avolio (1990). This positive empirical evidence also provides that the leadership of the six large banks of Pakistan attempts to motivate the individual followers for producing expected outputs. Based on this empirical evidence, it could be stated that the leadership of these banks acts as their role models, provides individualized considerations, acts as coaches and mentors and is contributing in the overall development of the individuals Bass and Riggio (2006).

In addition, the results of the present study have revealed that 8.7 percent of the variance is explained by the transformational leadership in the job performance of branch managers of six large banks of Pakistan. This suggested that the transformational leadership plays a positive role in enhancing the individual job performance in the investigated settings. These results are also in line with other studies that support the positive association between transformational leadership and job performance (Dolatabadi and Safa (2010); Mohammad Mosadegh Rad and Hossein Yarmohammadian (2006); Shah et al. (2015); Voon et al. (2011)). In the light of Leader Member Exchange (LXM) theory Graen (1976), this study provides empirical evidence that transformational leadership contributes positively in the increasing the job performance of bank managers. The investigation of transformational leadership and job performance relationship was mainly conducted in the six large banks of Pakistan. Therefore, the future researchers may increase the scope of this investigation for further confirming the results of the present study, preferably at the country level by incorporating the public and private banks and other financial institutions. It shows that there are other factors which are more than 90 percent, that can influence to enhance job performance additionally, the present study used cross-sectional design. Therefore, it is suggested that in future a longitudinal based analysis may be performed.

\section{Conclusion}

The objective of the present study was to assess the results pertaining to the effectiveness of transformational leadership and job performance relationship in the light of LMX theory. This assessment has provided empirical evidence in the Pakistani context suggesting that transformational leadership is perceived important by the bank managers in the six large banks of Pakistan. 


\section{References}

Alimo-Metcalfe, B., \& Alban-Metcalfe, J. (2005). Leadership: time for a new direction? Leadership, 1(1), 51-71.

Argyris, C., \& Schön, D. A. (1996). Organisational learning II: Theory, method and practice. Reading: Addison-Wesley.

Austin, J. T., \& Villanova, P. (1992). The criterion problem: 1917-1992. Journal of Applied Psychology, 77(6), 836.

Avolio, B. J., Bass, B. M., \& Zhu, F. W. W. (2004). Multifactor leadership questionnaire: manual and sampler set: Mind Garden Redwood City, CA.

Bagozzi, R. P., \& Yi, Y. (1988). On the evaluation of structural equation models. Journal of the academy of marketing science, 16(1), 74-94.

Barclay, D., Higgins, C., \& Thompson, R. (1995). The partial least squares (PLS) approach to causal modeling: Personal computer adoption and use as an illustration. Technology studies, 2(2), 285-309.

Bass, B. M. (1985). Leadership and performance beyond expectations: Collier Macmillan.

Bass, B. M., \& Avolio, B. J. (1990). Transformational leadership development: Manual for the multifactor leadership questionnaire: Consulting Psychologists Press.

Bass, B. M., \& Avolio, B. J. (1995). Multifactor leadership questionnaire: Manual leader form, rater, and scoring key for MLQ (Form 5x-Short). Mind Garden, Redwood City, CA.

Bass, B. M., Avolio, B. J., Jung, D. I., \& Berson, Y. (2003). Predicting unit performance by assessing transformational and transactional leadership. Journal of Applied Psychology, 88(2), 207.

Bass, B. M., \& Riggio, R. E. (2006). Transformational Leadership . Mahwah, NJ: L. I Lawrence Erlbaum.

Beck, T., Behr, P., \& Guettler, A. (2012). Gender and banking: Are women better loan officers? Review of Finance, rfs028.

Borman, W. C., \& Motowidlo, S. (1993). Expanding the criterion domain to include elements of contextual performance. Personnel Selection in Organizations; San Francisco: Jossey-Bass, 71.

Borman, W. C., \& Motowidlo, S. J. (2014). Organizational citizenship behavior and contextual performance: A special issue of human performance: Psychology Press.

Campbell, J. P. (1990). The role of theory in industrial and organizational psychology.

Chin, W. W. (1998). The partial least squares approach to structural equation modeling. Modern methods for business research, 295(2), 295-336.

Chu, H.-C., Yang, Y.-F., \& Chen, C.-Y. (2011). The dyadic effect of leadership and conflict management on trust in the context of life insurance companies in Taiwan. African Journal of Business Management, 5(11), 4272.

Sukkur IBA Journal of Management and Business | Volume 3 No. 2 July - December 2016 ๔ Sukkur Institute of Business Administration 
Dolatabadi, H. R., \& Safa, M. (2010). The effect of directive and participative leadership style on employees' commitment to service quality. International Bulletin of Business Administration, 9, 31-42.

Dvir, T., Eden, D., Avolio, B. J., \& Shamir, B. (2002). Impact of transformational leadership on follower development and performance: A field experiment. Academy of management journal, 45(4), 735-744.

Ehrhart, M. G. (2004). Leadership and procedural justice climate as antecedents of unitlevel organizational citizenship behavior. Personnel Psychology, 57(1), 61-94.

Fornell, C., \& Larcker, D. F. (1981). Evaluating structural equation models with unobservable variables and measurement error. Journal of marketing research, 39-50.

Gardner, L., \& Stough, C. (2002). Examining the relationship between leadership and emotional intelligence in senior level managers. Leadership \& organization development journal, 23(2), 68-78.

Glynn, M. A. (1996). Innovative genius: A framework for relating individual and organizational intelligences to innovation. Academy of management review, 21(4), 1081-1111.

Graen, G. (1976). Role-making processes within complex organizations. Handbook of industrial and organizational psychology, 1201, 1245.

Hair, J. F., Ringle, C. M., \& Sarstedt, M. (2011). PLS-SEM: Indeed a silver bullet. Journal of Marketing theory and Practice, 19(2), 139-152.

Hair, J. F., Sarstedt, M., Ringle, C. M., \& Mena, J. A. (2012). An assessment of the use of partial least squares structural equation modeling in marketing research. Journal of the academy of marketing science, 40(3), 414-433.

Hochwarter, W. A., Kiewitz, C., Gundlach, M. J., \& Stoner, J. (2004). The impact of vocational and social efficacy on job performance and career satisfaction. Journal of Leadership \& Organizational Studies, 10(3), 27-40.

Hourani, L. L., Williams, T. V., \& Kress, A. M. (2006). Stress, mental health, and job performance among active duty military personnel: findings from the 2002 Department of Defense Health-Related Behaviors Survey. Military medicine, 171(9), 849.

Hurley, R. F., \& Hult, G. T. M. (1998). Innovation, market orientation, and organizational learning: an integration and empirical examination. The Journal of Marketing, 42-54.

Ittner, C. D., Larcker, D. F., \& Pizzini, M. (2007). Performance-based compensation in member-owned firms: An examination of medical group practices. Journal of Accounting and Economics, 44(3), 300-327.

Jamal, M. (2007). Job stress and job performance controversy revisited: An empirical examination in two countries. International journal of stress management, 14(2), 175.

Janssen, O., \& Van Yperen, N. W. (2004). Employees' goal orientations, the quality of leader-member exchange, and the outcomes of job performance and job satisfaction. Academy of management journal, 47(3), 368-384.

Sukkur IBA Journal of Management and Business | Volume 3 No. 2 July - December 2016 @ Sukkur Institute of Business Administration 
Kanter, R. M. (1988). Three tiers for innovation research. Communication Research, 15(5), 509-523.

Katz, D., \& Kahn, R. L. (1978). The social psychology of organizations (Vol. 2): Wiley New York.

Kelman, H. C. (1958). Compliance, identification, and internalization three processes of attitude change. Journal of conflict resolution, 2(1), 51-60.

Krejcie, R. V., \& Morgan, D. W. (1970). Determining sample size for research activities. Educational and psychological measurement, 30(3), 607-610.

Lau, Y. W., \& Tong, C. Q. (2008). Are Malaysian government-linked companies (GLCs) creating value. International Applied Economics and Management Letters, 1(1), 9-12.

Lee, O. F., Tan, J. A., \& Javalgi, R. (2010). Goal orientation and organizational commitment: Individual difference predictors of job performance. International Journal of Organizational Analysis, 18(1), 129-150.

Levy, P. E., Cober, R. T., \& Miller, T. (2002). The effect of transformational and transactional leadership perceptions on feedback-seeking intentions. Journal of Applied Social Psychology, 32(8), 1703-1720.

Luthans, F., Avey, J. B., Avolio, B. J., \& Peterson, S. J. (2010). The development and resulting performance impact of positive psychological capital. Human resource development quarterly, 21(1), 41-67.

McCloy, R. A., Campbell, J. P., \& Cudeck, R. (1994). A confirmatory test of a model of performance determinants. Journal of Applied Psychology, 79(4), 493.

Mohammad Mosadegh Rad, A., \& Hossein Yarmohammadian, M. (2006). A study of relationship between managers' leadership style and employees' job satisfaction. Leadership in Health Services, 19(2), 11-28.

Motowidlo, S. J., \& Van Scotter, J. R. (1994). Evidence that task performance should be distinguished from contextual performance. Journal of Applied Psychology, 79(4), 475.

Motowildo, S. J., Borman, W. C., \& Schmit, M. J. (1997). A theory of individual differences in task and contextual performance. Human performance, 10(2), 71-83.

Ng, T. W., \& Feldman, D. C. (2008). The relationship of age to ten dimensions of job performance: American Psychological Association.

Organ, D. W. (1977). A reappraisal and reinterpretation of the satisfaction-causesperformance hypothesis. Academy of management review, 2(1), 46-53.

Organ, D. W. (1988). Organizational citizenship behavior: The good soldier syndrome: Lexington Books/DC Heath and Com.

Orr, J. M., Sackett, P. R., \& Mercer, M. (1989). The role of prescribed and nonprescribed behaviors in estimating the dollar value of performance. Journal of Applied Psychology, 74(1), 34.

Ringle, C. M., Wende, S., \& Will, A. (2005). SmartPLS 2.0 (beta): Hamburg. 
Sarros, J. C., \& Santora, J. C. (2001). The transformational-transactional leadership model in practice. Leadership \& organization development journal, 22(8), 383394.

Shah, S. M. M., Hamid, A., \& Bin, K. (2015). Transactional Leadership and Job Performance: An Empirical Investigation. Sukkur IBA Journal of Management and Business, 2(2), 69-81.

Voon, M. L., Lo, M. C., Ngui, K. S., \& Ayob, N. B. (2011). The influence of leadership styles on employees' job satisfaction in public sector organizations in Malaysia. International Journal of Business, Management and Social Sciences, 2(1), 2432.

Wang, G., Oh, I.-S., Courtright, S. H., \& Colbert, A. E. (2011). Transformational leadership and performance across criteria and levels: A meta-analytic review of 25 years of research. Group \& Organization Management, 36(2), 223-270.

Whetstone, J. T. (2002). Personalism and moral leadership: The servant leader with a transforming vision. Business Ethics: A European Review, 11(4), 385-392.

Williams, L. J., \& Anderson, S. E. (1991). Job satisfaction and organizational commitment as predictors of organizational citizenship and in-role behaviors. Journal of management, 17(3), 601-617. 